\title{
THE DEMOGRAPHIC AND CLINICAL STUDY OF HOARSENESS OF VOICE
}

\author{
Murugesan Kanakaraj Siddhartharaj', Puthiya Veetil Haridas ${ }^{2}$ \\ 1 Professor, Department of ENT, Chengalpattu Medical College. \\ ${ }^{2}$ Associate Professor, Department of ENT, Chengalpattu Medical College.
}

\begin{abstract}
Hoarseness of voice is a common clinical condition often encountered in ENT practice. The management of this condition is to treat the cause. The Clinical Study on aetiopathogenesis of hoarseness of voice was conducted among 50 patients in the Department of ENT, Chengalpattu Medical College, Chengalpattu, Tamil Nadu, S. India, during the period from June 2015 to Dec 2015 . The present study was conducted to categorise the various diseases of the larynx causing hoarseness directly or indirectly. Evaluation of the recent trends in the age, incidence, sex ratio and occupational factors. All the patients were asked detailed history, past history and both general and ENT examination were conducted to find the cause of hoarseness of voice clinically using a standard proforma. All the relevant investigations were done after obtaining written consent from the patients. The observation and results are depicted in the form of Tabular column, Histograms and Pie chart. In our study, malignancy of larynx and laryngopharynx was the commonest ethology and paralysis of vocal cord was the least in the semi-urban based medical college. Under benign glottic conditions, vocal cord polyp was the commonest. There is male preponderance (68\%) in our study. Age Group $21-50$ (64\%) are predominantly affected. Among laryngeal malignancies, glottic malignancy was common (50\%) and histologically well-differentiated squamous cell carcinoma. In hypopharyngeal malignancies, pyriform fossa malignancy (90\%) was commonest and histologically poorly differentiated squamous cell carcinoma. Left recurrent laryngeal nerve was commonly affected (75\%) with male preponderance.
\end{abstract}

\section{KEYWORDS}

Hoarseness of Voice, Aetiopathogenesis and Clinical Study.

HOW TO CITE THIS ARTICLE: Siddhartharaj MK, Haridas PV. The demographic and clinical study of hoarseness of voice. J. Evolution Med. Dent. Sci. 2016;5(59):4120-4126, DOI: 10.14260/jemds/2016/942

\section{INTRODUCTION}

One of the important factor, which sets man apart from all living organisms which make him unique is his ability to communicate using his vocal tone for social interactions FISHER.

Voice is defined as Laryngeal tone, which can be heard or measured. ${ }^{1}$ The normal human voice should have certain characteristics like pitch, tone and quality which makes the meaning clear and arouse the emotional response to endure a pleasant tonal effect upon the listener.

Hoarseness of voice may be defined as a quality of voice which is rough, grating, harsh more or less discordant and lower in pitch than normal voice. Hoarseness is purely a relative term.

\section{Mechanical Elements in this Process are. ${ }^{2}$}

1. Approximation of voice cords

2. Firming/Hardening of vocal cord edges

3. Vibration of the vocal cords.

When normal voice is affected, their communication becomes difficult resulting in serious handicap and embarrassment to the speaker.

Now with the advance in micro-laryngeal techniques, one can detect early lesion from the vocal cords and microsurgical procedures can be adopted without much trauma to the surrounding tissues and thereby conservation of voice is better. Much advanced procedures like Stroboscopy. ${ }^{3}$

Financial or Other, Competing Interest: None

Submission 14-06-2016, Peer Review 09-07-2016,

Acceptance 15-07-2016, Published 25-07-2016.

Corresponding Author:

Dr. Puthiya Veetil Haridas,

Plot No. 18, $7^{\text {th }}$ Street

Periyar Nagar,

IAF Avadi,

Chennai.

E-mail: hdas3062@gmail.com

DOI: $10.14260 /$ jemds/2016/942
Cineradiography, tape recording, phonography spirometry, glottography, oscillography and electromyography will help in assessing the impairment of the vocal cord movement during the disease process and also in assisting the improvement of vocal cord vibration during recovery after the treatment.

Jackson and Norris. ${ }^{4} 1961$ and Gron 1966 have published the application of CT and MRI in Laryngology.

Manguso and Hanfe.1,4 1982 have done extensive study of the larynx by using CT in benign tumours and laryngeal trauma.

Cummings et $\mathrm{al}^{5}$ showed benign vocal fold mucosal disorders, eg. Vocal nodules, laryngeal polyps caused primarily by vibratory trauma.

Cummings et al showed that malignant tumours of the larynx and hypopharynx occurs more commonly in $50-60$ year old man, closely associated with cigarette smoking and alcohol abuse.

Benjamin B, Croxson. ${ }^{6} \mathrm{G}$ et al studied series of 16 vocal cord granuloma in adults and children.

Chopra H, Kapoor.7 conducted the "study of benign glottic lesions undergoing microlaryngeal surgery."

The present study is conducted to identify this aetiopathology of hoarseness of voice and creating awareness among people about misuse of voice, excessive smoking and alcohol consumption.

\section{MATERIALS AND METHODS}

The clinical study on aetiopathogenesis of hoarseness of voice was conducted in the Department of ENT, Govt. Chengalpattu Medical College, Chengalpattu.

Government Chengalpattu Medical College is a semi-urban Medical College.

50 patients with hoarseness of voice during the period from June 2015 to Dec 2015 were studied. 
All the patients were asked detailed history, past history and both general and ENT examination were conducted to find the cause of hoarseness of voice clinically using a standard proforma. Special attention was given to examination of neck, cardiovascular system, respiratory system and central nervous system.

Investigations included indirect laryngoscopic examination, X-ray of chest (PA view), blood sugar, serology, $\mathrm{X}$-ray neck, lateral and AP view, barium swallow, sputum for AFB, urine analysis, direct laryngoscopy, bronchoscopy and biopsy for HPE. Study was conducted only after informing the patients and obtaining their consent.

\section{OBSERVATIONS AND RESULTS}

\begin{tabular}{|c|c|c|}
\hline $\begin{array}{c}\text { Sl. } \\
\text { No. }\end{array}$ & Causes & $\begin{array}{c}\text { Percentage } \\
\text { (Present Series) }\end{array}$ \\
\hline 1 & Malignancy of Larynx & $10(20 \%)$ \\
\hline 2 & Malignancy of Hypopharynx & $10(20 \%)$ \\
\hline
\end{tabular}

\section{Showing Causes of Hoarseness of Voice in 50 Cases}

\begin{tabular}{|c|c|c|}
\hline 3 & Acute Laryngitis & $8(16 \%)$ \\
\hline 4 & Chronic Laryngitis & $8(16 \%)$ \\
\hline 5 & $\begin{array}{c}\text { Benign Tumours of the } \\
\text { Larynx }\end{array}$ & $10(20 \%)$ \\
\hline 6 & Vocal Cord Paralysis & $4(8 \%)$ \\
\hline \multicolumn{2}{|c|}{ Table 1: Showing Causes of Hoarseness } \\
of Voice in 50 Cases
\end{tabular}

Present study shows commonest aetiological factor causing hoarseness of voice was malignancy of larynx and laryngopharynx (40\%); laryngeal malignancy and laryngopharyngeal malignancies leading the table with $20 \%$ followed by benign tumours of the larynx $20 \%$, acute laryngitis $16 \%$, chronic laryngitis $16 \%$ and vocal cord paralysis $8 \%$.

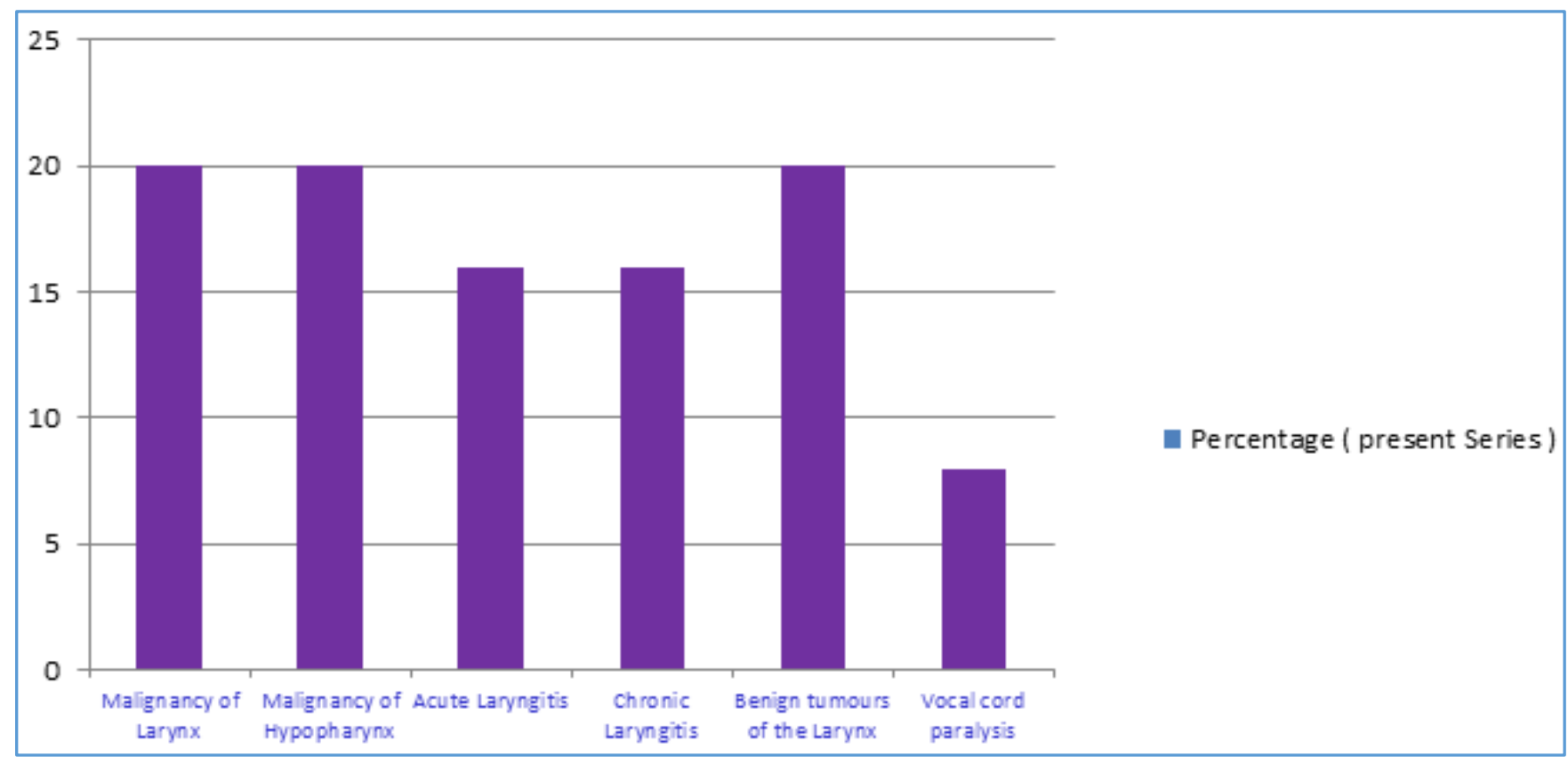

\begin{tabular}{|c|c|}
\hline Sex & Percentage (Present Series) \\
\hline Male & $34(68 \%)$ \\
\hline Female & $16(32 \%)$ \\
\hline \multicolumn{3}{|c|}{ Table 2: Showing Distribution in } \\
& 50 Cases of Hoarseness of Voice \\
\hline
\end{tabular}

Present study male distribution is about $68 \%$ and Female $32 \%$ with male predominance. Age distribution in 50 cases of hoarseness of voice.

\begin{tabular}{|c|c|}
\hline Age & Percentage (Present Series) \\
\hline $0-10$ & $1(2 \%)$ \\
\hline $11-20$ & $1(2 \%)$ \\
\hline $21-30$ & $8(16 \%)$ \\
\hline $31-40$ & $8(16 \%)$ \\
\hline $41-50$ & $16(32 \%)$ \\
\hline$>51$ & $16(32 \%)$ \\
\hline
\end{tabular}

Shows $21-50$ age group predominantly affected $64 \%$ followed by more than 50 years' age group (32\%). So patients in active age group are commonly affected.

\begin{tabular}{|c|c|c|}
\hline Site & $\begin{array}{c}\text { No. of } \\
\text { Patients }\end{array}$ & $\begin{array}{c}\text { Percentage } \\
\text { (Present Series) }\end{array}$ \\
\hline Supraglottis & 2 & $20 \%$ \\
\hline Glottis & 5 & $50 \%$ \\
\hline Subglottis & 1 & $10 \%$ \\
\hline Transglottis & 2 & $20 \%$ \\
\hline \multicolumn{2}{|c|}{ Table 3: Showing Malignancy of Larynx } \\
Causing of Hoarseness of Voice
\end{tabular}

In present series, maximum case seen with hoarseness of voice were glottic malignancy about $50 \%$ followed by supraglottis $20 \%$, transglottis $20 \%$. 
Showing Malignancy of Larynx causing Hoarseness of Voice

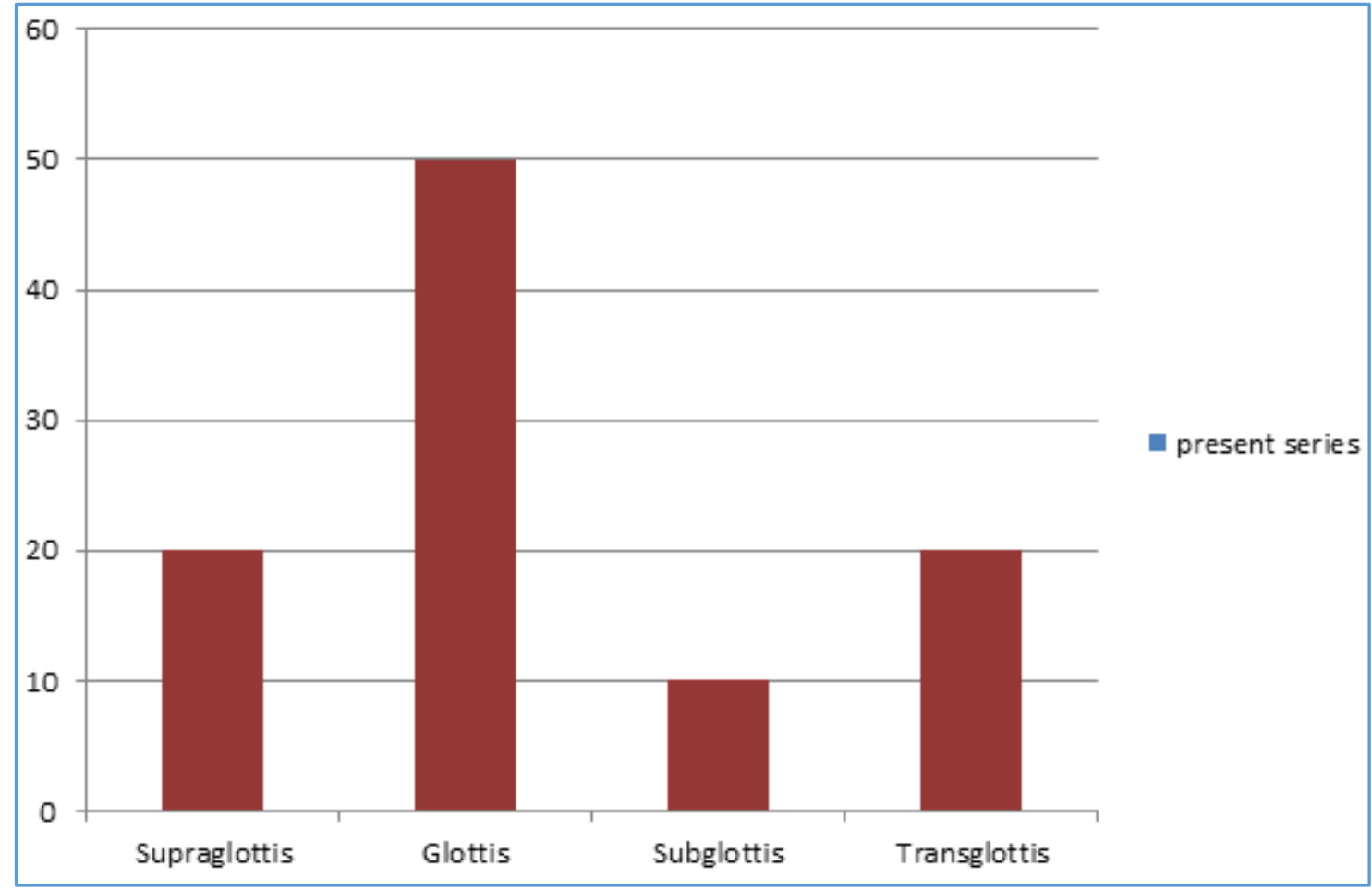

\begin{tabular}{|c|c|c|}
\hline Site & $\begin{array}{c}\text { No. of } \\
\text { Patients }\end{array}$ & $\begin{array}{c}\text { Percentage } \\
\text { (Present Series) }\end{array}$ \\
\hline Pyriform fossa & 9 & $90 \%$ \\
\hline $\begin{array}{c}\text { Posterior } \\
\text { pharyngeal wall }\end{array}$ & - & - \\
\hline Post-cricoid & 1 & $10 \%$ \\
\hline \multicolumn{2}{|c|}{ Table 4: Hypopharyngeal Malignancy } \\
Extending to the Larynx
\end{tabular}

\begin{tabular}{|c|c|}
\hline $41-50$ & $4(40 \%)$ \\
\hline $51-60$ & $3(30 \%)$ \\
\hline $61-70$ & $1(10 \%)$ \\
\hline$>70$ years & $1(10 \%)$ \\
\hline
\end{tabular}

In malignancy of Hypopharynx, more incidence is in $5^{\text {th }}$ decade followed by $6^{\text {th }}$ decade. Range was from $39-71$ years.

We observed that pyriform fossa malignancy $90 \%$ was the commonest hypopharyngeal malignancy extending to vocal cord causing hoarseness of voice followed by post-cricoid malignancy $10 \%$.

\begin{tabular}{|c|c|}
\hline Age & Percentage (Present Series) \\
\hline $0-10$ & 0 \\
\hline $11-20$ & 0 \\
\hline $21-30$ & 0 \\
\hline $31-40$ & $1(10 \%)$ \\
\hline $41-50$ & $3(30 \%)$ \\
\hline $51-60$ & $5(50 \%)$ \\
\hline $61-70$ & $1(10 \%)$ \\
\hline$>70$ years & 0 \\
\hline \multicolumn{2}{|c|}{ Table 5: Age Incidence in Patients } \\
with Malignancy of Larynx \\
\hline
\end{tabular}

Present series shows more incidence of malignancy occurring in the $6^{\text {th }}$ decade followed by $5^{\text {th }}$ decade. The range was from 39-66 years.

\begin{tabular}{|c|c|}
\hline Sex & Percentage (Present Series) \\
\hline Male & $9(90 \%)$ \\
\hline Female & $1(10 \%)$ \\
\hline \multicolumn{2}{|c|}{ Table 6: Sex Incidence in Malignancy of Larynx } \\
\hline
\end{tabular}

In present series shows laryngeal malignancy more common in males than females, $90 \%$ in males and $10 \%$ in females with the ratio of 9:1.

\section{Sex Incidence in Malignancy of Larynx}

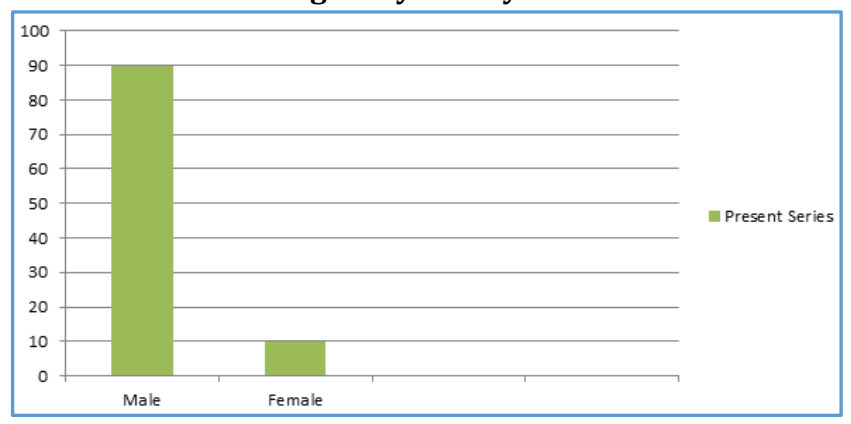

Age Incidence in Patients with Malignancy of Laryngopharynx

\begin{tabular}{|c|c|}
\hline Age & Percentage (Present Series) \\
\hline $0-10$ & 0 \\
\hline $11-20$ & 0 \\
\hline $21-30$ & 0 \\
\hline $31-40$ & $1(10 \%)$ \\
\hline
\end{tabular}

Sex Incidence of Malignancy of Laryngopharynx

\begin{tabular}{|c|c|}
\hline Sex & Percentage (Present Series) \\
\hline Male & $7(70 \%)$ \\
\hline Female & $3(30 \%)$ \\
\hline
\end{tabular}

Whereas in laryngopharynx malignancy also, males were commonly affected about (70\%) than females (30\%). 


\begin{tabular}{|c|c|}
\hline Habit & Percentage (Present Series) \\
\hline Smoking & $9(90 \%)$ \\
\hline Alcohol intake & $5(50 \%)$ \\
\hline Both & $5(50 \%)$ \\
\hline \multicolumn{2}{|c|}{ Table 7: Habits in Malignancy of Larynx } \\
\hline
\end{tabular}

The incident of heavy smoking is $90 \%$ in the present series; they smoked 20-30 bidis or cigarette daily for 10-30 years. The incidence of alcohol intake is $50 \%$ followed by both smoking and alcohol intake of $50 \%$.

\section{Habits in Malignancy of Larynx}

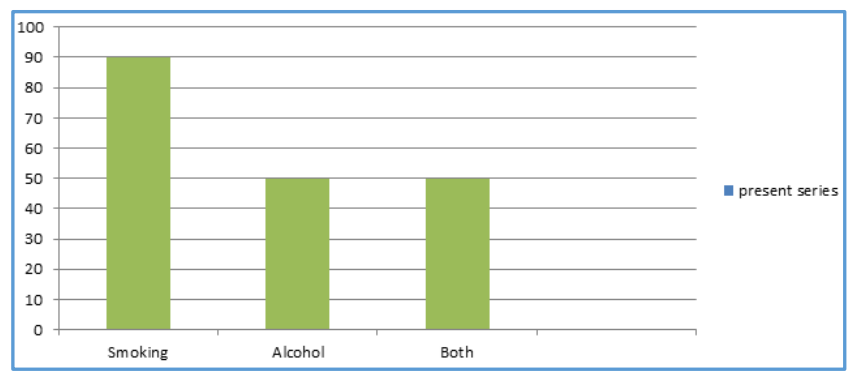

Habits in Malignancy of Laryngopharynx

\begin{tabular}{|c|c|}
\hline Habit & Percentage (Present Series) \\
\hline Smoking & $7(70 \%)$ \\
\hline Alcohol Intake & $5(50 \%)$ \\
\hline Both & $5(50 \%)$ \\
\hline
\end{tabular}

$70 \%$ of patients were smokers, used smoke $20-30$ bidis/cigarettes a day for $10-25$ years. Incidence of alcohol intake and both smoking and alcohol intake was $50 \%$.

\begin{tabular}{|c|c|}
\hline Stage & Percentage (Present Series) \\
\hline Stage 1 & $1(10 \%)$ \\
\hline Stage 2 & $4(40 \%)$ \\
\hline Stage 3 & $5(50 \%)$ \\
\hline Stage 4 & $0(0 \%)$ \\
\hline Table 8: Clinical Staging of Laryngeal Cancer \\
According to TNM Classification
\end{tabular}

Most of the patients presented in stage- 3 about $50 \%$ followed by stage $2(40 \%)$, most of the glottis tumours presented in stage 2 , supraglottic transglottic and subglottic in stage 3.

Clinical Staging of Laryngopharyngeal Cancer according to TNM Classification

\begin{tabular}{|c|c|}
\hline Stage & Percentage (Present Series) \\
\hline Stage 1 & 0 \\
\hline Stage 2 & $1(10 \%)$ \\
\hline Stage 3 & $9(90 \%)$ \\
\hline Stage 4 & 0 \\
\hline
\end{tabular}

Most of the patients with hoarseness of voice presented in stage 3 about $90 \%$.

\begin{tabular}{|c|c|}
\hline Type & $\begin{array}{c}\text { Percentage (Present } \\
\text { Series) }\end{array}$ \\
\hline Well-differentiated SCC & $7(70 \%)$ \\
\hline $\begin{array}{c}\text { Moderately-differentiated } \\
\text { SCC }\end{array}$ & $2(20 \%)$ \\
\hline \multicolumn{2}{|c|}{ Poorly-differentiated SCC } \\
\hline \multicolumn{2}{|c|}{ Table 9: Histological Type of Malignancy of Larynx } \\
\hline
\end{tabular}

Well-differentiated squamous cell carcinoma is more common about $70 \%$ followed by the moderately- and poorlydifferentiated $20 \%$ and $10 \%$ respectively.

Histological Type of Malignancy of Laryngopharynx

\begin{tabular}{|c|c|}
\hline Type & $\begin{array}{c}\text { Percentage } \\
\text { (Present Series) }\end{array}$ \\
\hline Well-differentiated SCC & 0 \\
\hline $\begin{array}{c}\text { Moderately-differentiated } \\
\text { SCC }\end{array}$ & $2(20 \%)$ \\
\hline Poorly-differentiated SCC & $8(80 \%)$ \\
\hline
\end{tabular}

Poorly-differentiated squamous cell carcinoma more common (80\%) in laryngopharyngeal malignancy. No case of well-differentiated type seen.

\begin{tabular}{|c|c|c|}
\hline SI. No. & Age & Percentage (Present Series) \\
\hline 1 & $0-10$ & 0 \\
\hline 2 & $11-20$ & 0 \\
\hline 3 & $21-30$ & $4(50 \%)$ \\
\hline 4 & $31-40$ & $2(25 \%)$ \\
\hline 5 & 41 onwards & $2(25 \%)$ \\
\hline \multicolumn{3}{|c|}{ Table 10: Age Incidence in Acute Laryngitis } \\
\hline
\end{tabular}

We observed that third decade was the commonest age group (50\%) affected by the acute laryngitis followed by the fourth decade $(25 \%)$.

\section{Age Incidence in Acute Laryngitis}

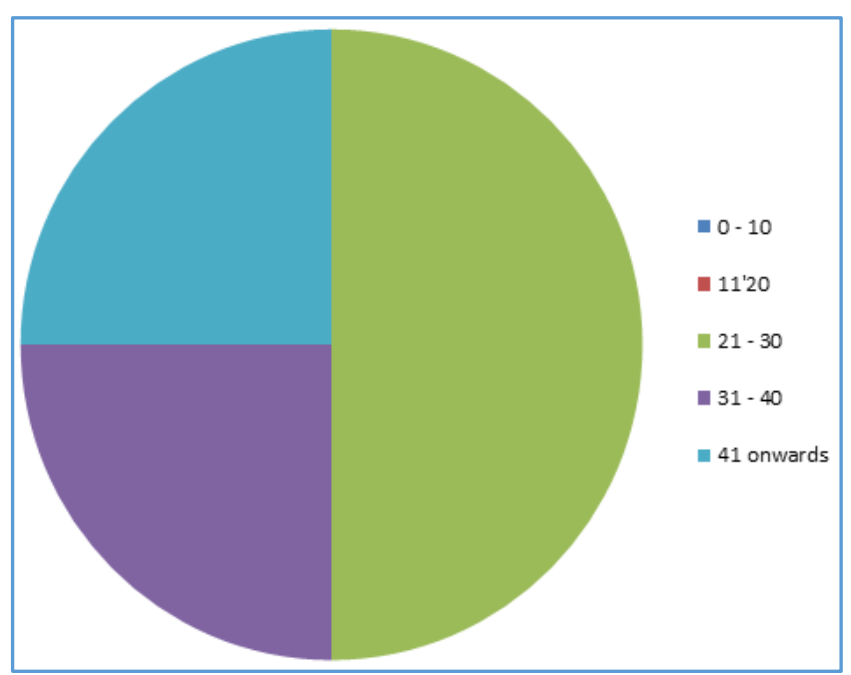

Sex Incidence in Acute Laryngitis

\begin{tabular}{|c|c|}
\hline Sex & Percentage (Present Series) \\
\hline Male & $(50 \%)$ \\
\hline Female & $(50 \%)$ \\
\hline
\end{tabular}

In present series, male (50\%) and Female (50\%) were equally affected. 


\section{Sex Incidence in Acute Laryngitis}

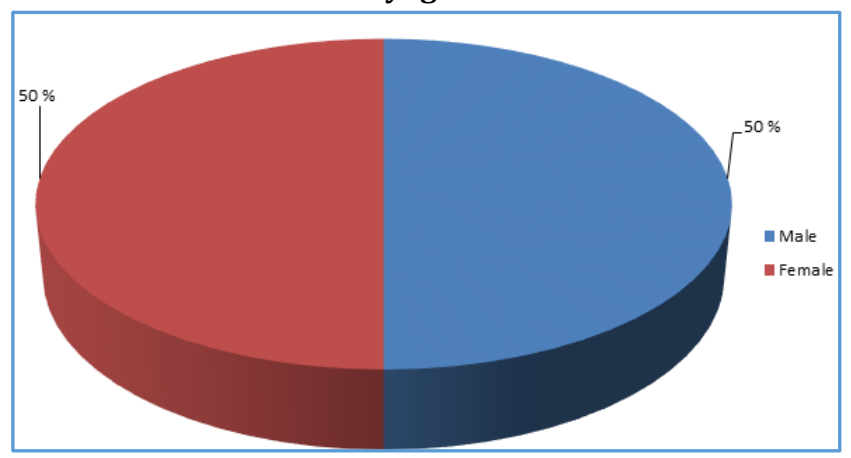

\begin{tabular}{|c|c|c|}
\hline $\begin{array}{c}\text { Sl. } \\
\text { No. }\end{array}$ & Cause & $\begin{array}{c}\text { Percentage (Present } \\
\text { Series) }\end{array}$ \\
\hline 1 & $\begin{array}{c}\text { Non-Specific chronic } \\
\text { laryngitis }\end{array}$ & $6(75 \%)$ \\
\hline 2 & Tuberculosis & $2(25 \%)$ \\
\hline \multicolumn{2}{|c|}{ Table 11: Causes of Chronic Laryngitis } \\
\hline
\end{tabular}

From the present series, it was observed that nonspecific chronic laryngitis is the commonest cause for chronic laryngitis about $75 \%$ followed by the tuberculosis $25 \%$.

\section{Sex Incidence in Chronic Laryngitis}

\begin{tabular}{|c|c|c|}
\hline Sl. No. & Sex & Percentage (Present Series) \\
\hline 1 & Male & $6(75 \%)$ \\
\hline 2 & Female & $2(25 \%)$ \\
\hline
\end{tabular}

We observed that male $(75 \%)$ patients were more affected than female patients $(25 \%)$.

\begin{tabular}{|c|c|c|}
\hline Sl. No. & Cause & Percentage (Present Series) \\
\hline 1 & Vocal Nodule & $2(20 \%)$ \\
\hline 2 & Vocal Polyp & $4(40 \%)$ \\
\hline 3 & Papilloma & $3(30 \%)$ \\
\hline 4 & Miscellaneous & $1(10 \%)$ \\
\hline \multicolumn{3}{|c|}{ Table 12: Benign Glottic Lesions } \\
\hline
\end{tabular}

In present series vocal cord polyp occurs most frequently $40 \%$ followed by vocal cord papilloma, $30 \%$ vocal nodule, $20 \%$ males more affected in vocal polyp, whereas females were more frequently affected in vocal nodule. One child presented with multiple papilloma and another lady with laryngeal web which was operated once.

\section{Benign Glottic Lesions}

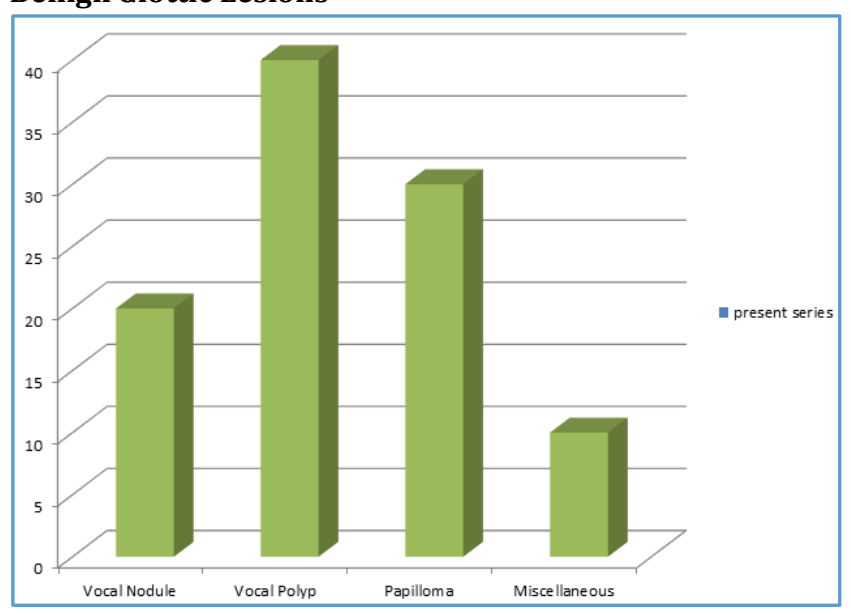

\begin{tabular}{|c|c|c|}
\hline Sl. No. & Age & Percentage (Present Series) \\
\hline 1 & $0-10$ & $2(20 \%)$ \\
\hline 2 & $11-20$ & 0 \\
\hline 3 & $21-30$ & $3(30 \%)$ \\
\hline 4 & $31-40$ & $3(40 \%)$ \\
\hline 5 & $41-50$ & $1(10 \%)$ \\
\hline 6 & $51-60$ & 0 \\
\hline 7 & $61-70$ & Table 13: Age Incidence in Benign Glottic Lesions \\
\hline
\end{tabular}

In present series, incidence of benign glottic lesions commonly occurs in the age group of $21-50$ years.

\section{Sex Incidence in Benign Glottic Lesions}

\begin{tabular}{|c|c|c|}
\hline Sl. No. & Sex & Percentage (Present Series) \\
\hline 1 & Male & $5(50 \%)$ \\
\hline 2 & Female & $5(50 \%)$ \\
\hline
\end{tabular}

In present series, male and female were equal (50\%).

\begin{tabular}{|c|c|c|}
\hline Sl. No. & Causes & $\begin{array}{c}\text { Percentage } \\
\text { (Present Series) }\end{array}$ \\
\hline 1 & Idiopathic & $2(50 \%)$ \\
\hline 2 & Thyroidectomy & $1(25 \%)$ \\
\hline 3 & Malignancy & $1(25 \%)$ \\
\hline \multicolumn{2}{|c|}{ Table 14: Causes of Vocal Cord Paralysis causing } \\
Hoarseness of Voice
\end{tabular}

Causes of Vocal Cord Paralysis causing Hoarseness of Voice

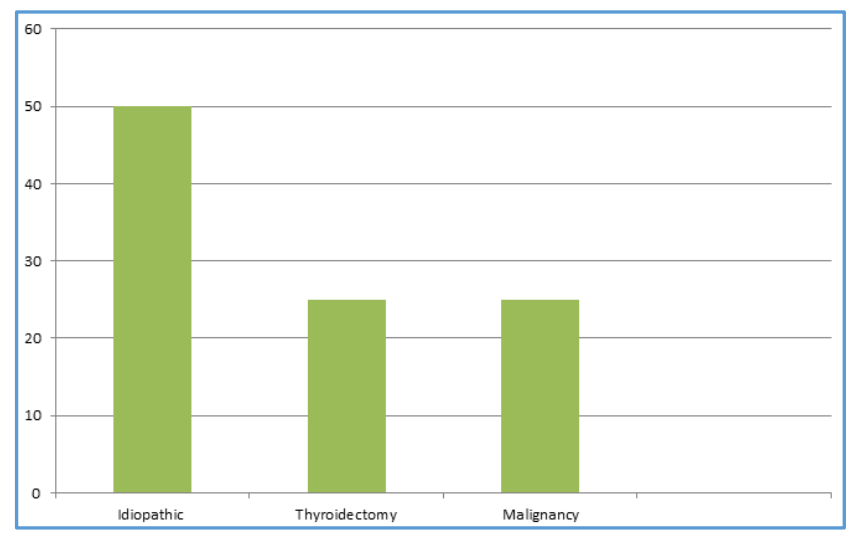

\begin{tabular}{|c|c|}
\hline Side of Lesion & $\begin{array}{c}\text { Percentage } \\
\text { (Present Series) }\end{array}$ \\
\hline Right recurrent laryngeal N & $1(25 \%)$ \\
\hline Left recurrent laryngeal N & $3(75 \%)$ \\
\hline \multicolumn{2}{|c|}{ Table 15: Analysis of Site of Lesion } \\
of Laryngeal Nerve Paralysis
\end{tabular}

In present series occurrence of left recurrent laryngeal nerve paralysis, more common about $75 \%$ followed by right recurrent laryngeal nerve paralysis $25 \%$.

\begin{tabular}{|c|c|c|}
\hline Sl. No. & Age & $\begin{array}{c}\text { Percentage } \\
\text { (Present Series) }\end{array}$ \\
\hline 1 & $0-10$ & 0 \\
\hline 2 & $11-20$ & 0 \\
\hline 3 & $21-30$ & $1(25 \%)$ \\
\hline 4 & $31-40$ & $1(25 \%)$ \\
\hline 5 & $41-50$ & $2(50 \%)$ \\
\hline 6 & $51-60$ & 0 \\
\hline 7 & 60 above & 0 \\
\hline \multicolumn{2}{|c|}{ Table 16: Age Incidence in Vocal Cord Paralysis } \\
\hline
\end{tabular}


In present series, $5^{\text {th }}$ decade was the commonest age group affected about $50 \%$ followed by $4^{\text {th }} 25 \%$ and $3^{\text {rd }}(25 \%)$.

\section{Age Incidence in Vocal Cord Paralysis}

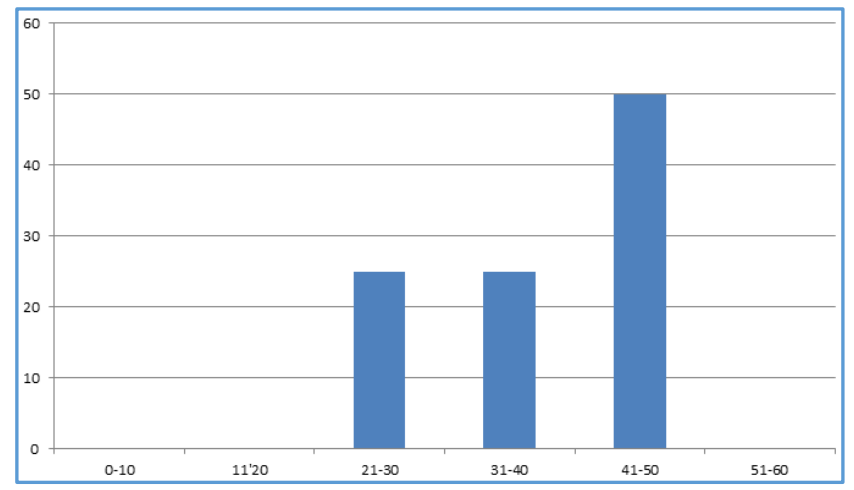

Sex Incidence in Vocal Cord Paralysis

\begin{tabular}{|c|c|}
\hline Sex & Percentage (Present Series) \\
\hline Male & $3(75 \%)$ \\
\hline Female & $1(25 \%)$ \\
\hline
\end{tabular}

In present series, male are commonly affected $75 \%$ than the females about $25 \%$.

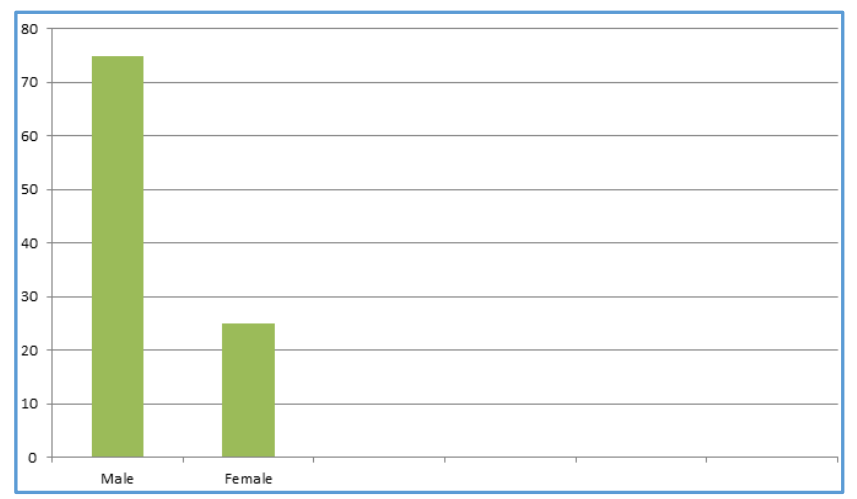

\section{DISCUSSION}

Fifty cases of hoarseness of voice were examined and investigated to determine the aetiological conditions.

The cause of hoarseness of voice were enumerated in Table -1

Commonest cause being the malignancy of larynx and laryngopharynx about $40 \%$ followed by the benign lesions of the larynx about $20 \%$, acute laryngitis $16 \%$, vocal cord paralysis $8 \%$, chronic laryngitis $16 \%$. Parikh N.P. (1991) showed $12 \%$ cases of laryngeal malignancy caused hoarseness.

\section{Age and Sex (Table - 2)}

In the present study of cases, males were commonly affected $68 \%$, females $32 \%$. Parikh N.P. 8 (1991) observed that $67 \%$ males and $33 \%$ of females affected.

Higher prevalence of Hoarseness observed in 21-50 years of age group in present study. This higher prevalence in males and in 21-50 years could be due to:

1. Habits like - smoking, alcohol intake.

2. More exposure to occupational hazards, which are denied to women who mostly lead an indoor life.
Malignancy of Larynx and Laryngopharynx (Table 3 and 4)

In the present study majority of cases, i.e. $40 \%$ cases of hoarse voice caused by malignant tumour of larynx and laryngopharynx. This increased number of cases in our series may be due to as our institute acts as tertiary referral centre.

In laryngeal malignancy (Table 3) commonest being the glottis $(50 \%)$ one followed by supraglottic, transglottic and subglottic. This can be reflected in Moreau. ${ }^{9}$ series and Deka R.C. series, where glottis malignancy is the predominant cause for hoarseness of voice; Where in M.F. Vega et al ${ }^{10}$ and Das and Bose. ${ }^{11}$ series supraglottic was the predominant site.

In hypopharyngeal malignancy (Table 4), almost all cases presents with advanced lesions in T3 and T4 stages extending to the larynx. Pyriform fossae tumours being the commonest with $90 \%$.

Barua et al 12 and Paymaster in their series showed about $28 \%$ of cases were presented with hoarseness of voice.

\section{Age (Table - 5)}

Vega M.F. ${ }^{10}$ et al and Das and Bose. ${ }^{11}$ series showed laryngeal malignancy occurs more commonly in age group of $50-60$ years $(50 \%)$ followed by $5^{\text {th }}$ decade $(30 \%)$ and $6^{\text {th }}$ decade $(24 \%$ and $30 \%)$ similar observation seen in our series.

\section{Sex (Table - 6)}

Present series show males (90\%) were affected more than females $(10 \%)$ in the laryngeal malignancy in the ratio of (9:1) Vega M.F. ${ }^{10}$ et al, Robin. ${ }^{13}$ et al (1991) and Das and Bose. ${ }^{11}$ series showed similar observations.

Barua $^{12}$ et al in their series showed $84.5 \%$ males and $15.5 \%$ females affected in the laryngopharyngeal malignancy.

\section{Habit (Table - 7)}

In present series, smoking (90\%) predominated habits in patients, smoking 20 - 30 bidis/cigarettes a day for 10-25 years. Alcohol intake is 50\%, both alcohol and smoking habit is $50 \%$.

Das and Bose series showed similar observation. Ramandan et $\mathrm{al}^{14}$ showed similar results.

Clinical Staging of Laryngeal and Laryngopharyngeal Cancer (Table - 8)

$5(50 \%)$ cases were classified as stage $4(40 \%)$ as stage 2,1 $(10 \%)$ cases in stage 1 , no cases were seen in stage 4 .

In our series most of the glottis carcinoma presented in stage 2, supra, sub and transglottic in stage 3.

In Das and Bose. ${ }^{11}$ series, stage 2 presented in $48.7 \%$ cases and stage 1 in $36.58 \%$ cases and only $10.97 \%$ in stage 3 .

\section{Histological Type (Table - 9)}

In laryngeal malignancy all cases were of squamous cell carcinoma, most were of well-differentiated type (70\%). Similar to Das and Bose. ${ }^{11}$ series (89\%). Whereas Parikh showed $50 \%$ case were of well-differentiated type.

\section{Age Incidence in Acute Laryngitis (Table - 10)}

Third decade was the commonest age group affected (50\%) followed by $4^{\text {th }}$ decade $(25 \%)$, males affected equally as females.

Adult cases appears to have been on increase as noted by Howlons et al (1973). In our series, adults were affected more 
commonly and upper respiratory tract infection and smoking were the predisposing factor.

It is observed that decrease in number of cases of acute laryngitis in children were may be due to,

- Improved child health care

- Better nutrition

- Widespread immunization

- Increased public health awareness of acute infections

- Increased cases of adults may be cause of overuse of voice and increase in smoking and alcohol intake.

\section{Chronic Laryngitis (Table - 11)}

In present study, we observed that non-specific laryngitis is the commonest cause of chronic laryngitis about $75 \%$.

Next commonest is tuberculous laryngitis about 25\%, both the cases were secondary to pulmonary tuberculosis.

\section{Benign Glottic Lesions (Table - 12 and 13)}

Males predominated in every category of benign laryngeal lesion, except in cases of vocal nodules. This is in accordance with study conducted by Holinger. ${ }^{15}$ et al and Chopra et al, in which $70 \%$ cases were males and $30 \%$ females. On the other hand females far exceeded the males in cases of vocal nodules. Sinha A et al showed males (73\%) more than females (7\%).

Chatterji and Saxena. ${ }^{16}$ series showed similar male predominance.

Kleinsasser showed similar observation as similar to present study.

\section{Vocal Cord Paralysis causing Hoarseness of Voice \\ (Table-14, 15, 16)}

In our study, idiopathic recurrent laryngeal nerve paralysis was of predominant variety $(50 \%)$. This can be reflected in Tucker. ${ }^{17}$ series, Ogura series and S. K. De. ${ }^{18}$ series.

Post-thyroidectomy is the next commonest iatrogenic traumatic injury causing vocal cord paralysis; this is shown in Parnell. ${ }^{19}$ series and Das. ${ }^{20}$ series.

Left recurrent laryngeal nerve paralysis (75\%) occurred more frequently than right on $(25 \%)$, similar to Stell and Maran series.

Vocal cord paralysis commonly observed in 41-50 years age group (50\%) followed by $3^{\text {rd }}$ and $2^{\text {nd }}$ decade. Similar observation made by S. K. De et al series (1976).

Males (75\%) were commonly affected than females (25\%) in the ratio of $3: 1$.

Similar male predominance seen in S. K. De et al series.

\section{CONCLUSION}

The aetiopathological study of 50 cases of hoarseness of voice revealed that,
a. Malignancy of larynx and laryngopharynx $-40 \%$.
b. Benign lesion of the glottis $-20 \%$.
c. Acute laryngitis - $16 \%$.
d. Chronic laryngitis - $16 \%$.
e. Vocal cord paralysis - $8 \%$.

Malignancy of larynx and laryngopharynx was the commonest aetiology. In benign glottic lesions, vocal polyp was the commonest. Vocal cord paralysis was seen more in male patients in $5^{\text {th }}$ decade. Majority of the patients were from rural background in lower socio-economic strata and majority were chronic smoker and alcoholic of long duration.
We advocate that in elderly people with hoarseness of voice of long duration ( $>3$ weeks) and having habit of smoking and alcohol intake, malignancy must be ruled out. Awareness must be created on the harmful effects of smoking and alcohol consumption. Awareness must also be created against the harmful effects of pollution of the environment.

\section{REFERENCES}

1. Robin PE, Olofsson J. Tumours of larynx. In: John H, ed. Scott brown's laryngology and HNS. $6^{\text {th }}$ ed. London: Butterworth-Heinemann 1997:3-25.

2. Neil W. Anatomy of the larynx and tracheobronchial tree. In: Michael G, ed. Scott brown's basic science. $6^{\text {th }}$ ed. Vol.1 London: Butterworth-Heinemann 1997:2-28.

3. Freeland AP. Acute laryngeal infections. In: Adams DA, Cinnamond MJ, et al. (eds) Scott Brown's paediatric otolaryngology. $6^{\text {th }}$ ed. Vol.6. London: ButterworthHeinmann 1997:1-16.

4. Silver CE. Historical aspects. Surgery for cancer of the larynx and related structures. New York: Churchill Livingstone 1981:1-10, 13-23.

5. Graney OD, Bastian RW. Benign vocal fold mucosal disorders. In: Cummings CW, ed. Otolaryngology HNS. $3^{\text {rd }}$ ed. Vol.3. London: Mosby 1998:1823-2298.

6. Benjamin B, Croxson G. Vocal cord granulomas. Ann Otol Rhinol Laryngol 1985;94(6 Pt 1):538-41.

7. Chopra H, Kapoor M. Study of benign glottis lesions undergoing microlaryngeal surgery. Ind J Otol HNS 1997;49(3):276-9.

8. Parikh NP. Aetiological study of 100 cases of hoarseness of voice. Ind J otol 1991;43(2):71-3.

9. Moreau PR. Treatment of laryngeal carcinoma by laser endoscopic microsurgery. Laryngoscope 2000;110(6): 1000-6.

10. Vega MF, Martinez T, Scola B, et al. The gregoria maranon hospital experience in the treatment of laryngeal carcinoma. IJO-HNS 1997;49(3):228-46.

11. Das BC, Bose M, et al. The prevalence of laryngeal cancer in bankura. IJO 1975;27(1):30-5.

12. Barua. Cancer of the hypopharynx a clinical study of 290 cases. IJO-HNS 1993;2(2):87-90.

13. Robin PE, Reid A, Powell DJ, et al. The incidence of cancer of the larynx. Clinical otolaryngology 1991;16(2):198-201.

14. Ramadan MF, Morton RP, Stell PM, et al. Epidemiology of laryngeal cancer. Clinical otolaryngology 1982;7(6): 417-28.

15. Holinger PH, Johnston KC. Benign tumours of the larynx. Annal of Otol, rhinol \& laryngol 1951;60:496-509.

16. Chatterji P, Saxena RK. Benign tumours of larynx. Ind J Otol 1974;26:17-21.

17. Tucker HM. Reinnervation of the unilaterally paralysed larynx. Ann otol rhinol laryngol 1997;86(6 Pt 1):789-94.

18. De SK. Aetiology of recurrent laryngeal nerve paralysis. Indian JLO 1976;2:21-5.

19. Parnell FW, Brandenberg JM. Vocal cord paralysis a review of 100 cases. Laryngoscope 1970;80(7):1036-45.

20. Das C. Laryngeal paralysis in thyroidectomy and disease of the thyroid gland. Indian Journal of Otol 1969;21(3): $121-5$. 